\title{
Two Flavonoid Compounds as Antiproliferative Activity Against SP-C1 Cancer Tongue Cells from the Leaves of Rasamala (Altingia excelsa Nornha)
}

\author{
Risyandi Anwar ${ }^{1}$, Arlette Setiawan ${ }^{2}$, Supriatno $^{3}$, Unang Supratman ${ }^{4,5}$ \\ ${ }^{1}$ Department of Pediatric Dentistry, Faculty of Dentistry, Universitas Muhammadiyah, Semarang 50273, Central \\ Java, Indonesia. \\ ${ }^{2}$ Department of Pediatric Dentistry, Faculty of Dentistry, Universitas Padjadjaran, Jatinangor 45363, \\ West Java, Indonesia. \\ ${ }^{3}$ Department of Oral Medicine, Faculty of Dentistry, Universitas Gadjah Mada, Jogjakarta 50125, Indonesia. \\ ${ }^{4}$ Department of Chemistry, Faculty of Mathematics and Natural Sciences, Universitas Padjadjaran, \\ Jatinangor 45363, West Java, Indonesia. \\ ${ }^{5}$ Central Laboratory, Universitas Padjadjaran, Jatinangor 45363, West Java, Indonesia.
}

E-mail: unang.supratman@unpad.ac.id

Received: February 2018; Revised: March 2018; Accepted: March 2018; Available Online: November 2018

\begin{abstract}
Two flavonoid compounds, kaempferol (1) and quercetin (2) have been isolated from the leaves of Rasamala (Altingia excelsa Nornha). The chemical structure of compounds $\mathbf{1}$ and $\mathbf{2}$ were identified by spectroscopic evidences including, UV, IR, 1D-NMR, 2D-NMR and MS as well as by comparing with previously reported spectral data.These compounds were isolated from this plant for the first time. Compounds $\mathbf{1}$ and $\mathbf{2}$ were evaluated for their antiproliferative activity against SP-C1 cancer tongue cells and showed $\mathrm{IC}_{50}$ values of 2.50 and $2.31 \mu \mathrm{M}$, respectively.
\end{abstract}

Keywords: Altingia excelsa, SP-C1 cancer tongue cells, kaempferol, quercetin.

DOI: http://10.15408/jkv.v4i2.7304

\section{INTRODUCTION}

Oral squamous cell cancer (OSCC) has high morbidity and mortality rates across the world because it is frequently found in advanced stages before therapy (Chen et al., 2008; Chen et al., 2013). The major environmental risk factors responsible for the development of cancer cell include betel nut chewing, cigarette smoking, alcohol consumption, and exposure to high-risk human papillomavirus. This cancer cell is a difficult disease to treat because of multidisciplinary and diverse treatment strategies and the varied natural behavior of the cancer. Local invasion and frequent regional lymph node metastases together with relative resistance to chemotherapeutic. The conventional strategies of cancer cell management still depend on surgery, radiotherapy, chemotherapy and targeted therapy (Shah and Gil 2009). The poor outcome of chemotherapy to oral squamous cell cancer contributes to the poor prognosis for this diseases (Scully and Bagan 2009). Therefore, novel, effective therapy for oral squamous cell cancer treatment is still needed. Due to this high incidence, the identification of novel compounds that inhibit cancer development has become a crucial objective for scientists. Hundreds of chemicals that have been and are being evaluated for their anti-cancer activities, natural products derived from medicinal plants rank among the most promising (Tan et al., 2011). During the course of our continuing search for novel anticancer compounds from Indonesian plants, the ethanol extract of the leaves of Altingia 
excelsa Nornha exhibited significant antiproliferative activity against SP-C1 cancer tongue cells. A. excelsa Nornha is known as Rasamala in Indonesia is higher plant. The plant is used in folklore and traditional medicine for the treatment of stomachache and coughs (Kanjijal et al., 2003; Pramono and Djam'an, 2002). Previous phytochemical study of this plant reported the presence of sesquiterpenoid from the leaves (Kanjijal et al., 2003), but antiproliferative compounds not yet reported. In this paper, we report the isolation and structure elucidation of two flavonoid compounds ( $\mathbf{1}$ and 2$)$ as antiproliferative activity against SP-C1 cancer tongue cells.

\section{MATERIAL AND METHODS General Experimental Procedure}

UV spectra were measured by using a TECAN Infinite M200 pro, with $\mathrm{MeOH}$. The IR spectra were recorded on a SHIMADZU IR Prestige- 21 in $\mathrm{KBr}$. The mass spectra were recorded with a Waters Xevo QTOF MS. NMR data were recorded on JEOL JNM A500 spectrometer at $500 \mathrm{MHz}$ for ${ }^{1} \mathrm{H}$ and 125 $\mathrm{MHz}$ for ${ }^{13} \mathrm{C}$, chemical shifts are given on a $\delta$ (ppm) scale with TMS as an internal standard. Column chromatography was conducted on silica gel 60. TLC plates were precoated with silica gel $\mathrm{GF}_{254}$ (Merck, $0.25 \mathrm{~mm}$ ) and detection was achieved by spraying with $10 \%$ $\mathrm{H}_{2} \mathrm{SO}_{4}$ in $\mathrm{EtOH}$, followed by heating and under UV light at wavelenght at 254 and $367 \mathrm{~nm}$.

\section{Plant Material}

The leaves of $A$. excelsa Nornha were collected in Wayang Windu mountain, Pangalengan, West Java Province, Indonesia in August 2015. The plant was identified by the staff of the Laboratory of Taxonomy, Department of Biology, Universitas Padjadjaran and a voucher specimen (No. $256 / \mathrm{HB} / 06 / 2015)$ was deposited at the herbarium.

\section{Plant Extraction}

Dried ground leaves $(2.5 \mathrm{~kg})$ of $A$. excelsa Nornha were extracted with methanol exhaustively $(15 \mathrm{~L})$ at room temperature for 5 days. The combined methanol extracts were then concentrated in vacuo at $40{ }^{\circ} \mathrm{C}$ to yield $254.5 \mathrm{~g}$ of residue. The residue was suspended in water and then partitioned, in turn, with $n$ hexane, EtOAc, and $n-\mathrm{BuOH}$. Evaporation resulted in the crude extracts of $n$-hexane $(20.90 \mathrm{~g})$, EtOAc $(35.18 \mathrm{~g})$, and $n$-butanol $(128.50 \mathrm{~g})$, respectively. The EtOAc soluble fraction $(30.0 \mathrm{~g})$ was fractionated by column chromatography on silica gel using a gradient $n$-hexane, EtOAc and $\mathrm{MeOH}$ to give eleven fractions $(\mathrm{A}-\mathrm{K})$. Fraction D $(1.85 \mathrm{~g})$ was subjected to column chromatography over silica gel using a gradient mixture of $n$-hexaneacetone (10:0-1:1) as eluting solvents to afford eight subfractions (D1-D8). Subfraction D5 (380 mg) was separated on a column of silica gel, eluted with $\mathrm{CHCl}_{3}: \mathrm{MeOH}$ (9:1), to give six subfractions (D5.1-D.5.6). Subfraction D5.3 (124.5 mg) was separated on preparative TLC on silica gel $\mathrm{GF}_{254}$ eluted with $\mathrm{CHCl}_{3}: \mathrm{MeOH}(9.5: 0.5)$ to give $1(28.5 \mathrm{mg})$. Subfraction D.5.4 (92.6 $\mathrm{mg})$ was chromatographed on a column chromatography of silica gel, eluted with $\mathrm{CHCl}_{3}: \mathrm{MeOH}(9.75: 0.25)$, to give $2(32.4 \mathrm{mg})$.

\section{Cell culture and treatment}

The SP-C1 human tongue cancer cell line used in this study were cultured in RPMI1640 medium (Sigma, St. Louis, MO, USA) supplemented with $10 \%$ fetal bovine serum and antibiotics $(100 \mathrm{U} / \mathrm{mL}$ penicillin and 100 $\mu \mathrm{g} / \mathrm{mL}$ streptomycin). For cell treatments, various concentrations of the sample were added to the cell culture medium. After $24 \mathrm{~h}$, the cells were released from treatment, the medium was replaced, and cells were subsequently collected at the indicated times (Prayitno et al., 2013).

\section{RESULT AND DISCUSSION}

The methanol extract from the dried leaves of A. excelsa Nornha were concentrated and extracted successively with $n$-hexane, ethyl acetate and $n$-butanol. The ethyl acetate extracts showed strongest antiproliferative activity against SP-C1 cancer tongue cells. By using antiproliferative activity assay to guide separations, the ethyl acetate fraction was separated by combination of column chromatography on silica gel G60 and preparative TLC on silica gel $\mathrm{GF}_{254}$ to afford two flavonoid compounds $\mathbf{1}$ and $\mathbf{2}$.

Kaempferol (1) - Yellow amorphous powder; UV (MeOH): $\lambda_{\max }(\log \varepsilon) 272$ (4.0), 364 (3.7) nm; IR (KBr) $v_{\max } \mathrm{cm}^{-1}$ : 3420, 1690, $1605 ;{ }^{1} \mathrm{H}-\mathrm{NMR}\left(\mathrm{CD}_{3} \mathrm{OD}, 500 \mathrm{MHz}\right): \delta_{\mathrm{H}} 7.15$ $\left(2 \mathrm{H}, \mathrm{d}, J=6.80 \mathrm{~Hz}, \mathrm{H}-2^{\prime}\right.$ and $\left.\mathrm{H}-6^{\prime}\right), 7.01(2 \mathrm{H}, \mathrm{d}$, 
$J=6.80 \mathrm{~Hz}, \mathrm{H}-3^{\prime}$ and $\left.\mathrm{H}-5^{\prime}\right), 6.52(1 \mathrm{H}, \mathrm{d}, J=1.95$ $\mathrm{Hz}, \mathrm{H}-8), 6.28(1 \mathrm{H}, \mathrm{d}, J=1.95 \mathrm{~Hz}, \mathrm{H}-6) ;{ }^{13} \mathrm{C}-$ NMR $\left(\mathrm{CD}_{3} \mathrm{OD}, 125 \mathrm{MHz}\right): \delta_{\mathrm{C}} 176.6(\mathrm{C}-4)$, 164.9 (C-7), 162.3 (C-5), 160.1 (C-4'), 157.7 (C-2), 146.9 (C-9), 136.6 (C-3), 130.4 (C-2'), $123.3\left(\mathrm{C}-1^{\prime}\right), 116.3$ (C-3'), 104.1 (C-10), 99.2 (C-6), 99.1 (C-6'), 94.5 (C-5'), 94.4 (C-8); LCMS ( $m / z$ 286).

Quercetin (2) - Yellow amorphous powder; UV (MeOH): $\lambda_{\max }(\log \varepsilon) 274$ (3.8), 360 (3.6) nm; IR (KBr) $v_{\max } \mathrm{cm}^{-1}: 3430,1680$, $1610 ;{ }^{1} \mathrm{H}-\mathrm{NMR}\left(\mathrm{CD}_{3} \mathrm{OD}, 500 \mathrm{MHz}\right): \delta_{\mathrm{H}} 7.73$ $\left(1 \mathrm{H}, \mathrm{d}, J=2.5 \mathrm{~Hz}, \mathrm{H}-2^{\prime}\right), 7.62(1 \mathrm{H}, \mathrm{dd}, J=8.5$, $\left.2.5 \mathrm{~Hz}, \mathrm{H}-6^{\prime}\right), 6.87\left(1 \mathrm{H}, \mathrm{d}, J=8.5 \mathrm{~Hz}, \mathrm{H}-5^{\prime}\right)$, $6.38(1 \mathrm{H}, \mathrm{d}, J=2.5 \mathrm{~Hz}, \mathrm{H}-8), 6.17(1 \mathrm{H}, \mathrm{d}, J=2.5$ $\mathrm{Hz}, \mathrm{H}-6) ;{ }^{13} \mathrm{C}-\mathrm{NMR}$ (CD $\left.3 \mathrm{OD}, 125 \mathrm{MHz}\right)$ : $\delta_{\mathrm{C}} 176.6$ (C-4), 165.0 (C-7), 162.4 (C-5), 157.8 (C-2), 148.4 (C-9), 147.0 (C-3'), 145.8 (C-4'), 136.8 (C-3), $124.5\left(\mathrm{C}-6^{\prime}\right), 121.5\left(\mathrm{C}-1^{\prime}\right), 116.2$ $\left(\mathrm{C}-2^{\prime}\right), 116.0\left(\mathrm{C}-5^{\prime}\right), 104.2$ (C-10), 99.2 (C-6), 94.5 (C-8); LC-MS spectral data $(\mathrm{m} / \mathrm{z}$ 302).

Compound 1 was obtained as yellow amorphous powder. The molecular formula was established to be $\mathrm{C}_{15} \mathrm{H}_{10} \mathrm{O}_{6}$ from its LCMS spectral data $(\mathrm{m} / z, 286)$ and NMR spectra, thus requiring eleven degrees of unsaturations. The UV spectrum of $\mathbf{1}$ showed $\lambda_{\max }$ at 272 and $364 \mathrm{~nm}$ and exhibited a bathochromic shift by added $\mathrm{NaOH}$ and $\mathrm{AlCl}_{3}$ suggested the presence of flavonoid structure with 4' and 5-hydroxyl groups. The IR spectrum of $\mathbf{1}$ showed the absorption band correspond to hydroxyl (3420 $\left.\mathrm{cm}^{-1}\right)$, carbonyl $\left(1690 \mathrm{~cm}^{-1}\right)$ and double bond $\left(1605 \mathrm{~cm}^{-1}\right)$ groups. The ${ }^{1} \mathrm{H}-\mathrm{NMR}$ spectrum of 1 showed the presence of meta-coupled of aromatic protons at $\delta_{\mathrm{H}} 6.28(1 \mathrm{H}, \mathrm{d}, J=1.95 \mathrm{~Hz})$ and $6.52(1 \mathrm{H}, \mathrm{d}, J=1.95 \mathrm{~Hz})$ corresponds to $\mathrm{H}$ 6 and H-8, respectively. The ${ }^{1} \mathrm{H}-\mathrm{NMR}$ spectrum of 1 also showed the presence of two doublet signals at $\delta_{\mathrm{H}} 7.15(2 \mathrm{H}, \mathrm{d}, J=6.80 \mathrm{~Hz}$, H-2 ${ }^{\prime}$ and $\left.\mathrm{H}-6^{\prime}\right)$ and $7.01(2 \mathrm{H}, \mathrm{d}, J=6.80 \mathrm{~Hz}, \mathrm{H}-$ $3^{\prime}$ and $\left.\mathrm{H}-5^{\prime}\right)$ corresponds to four aromatic protons in ring $\mathrm{B}$, characteristics for the $1^{\prime}, 4^{\prime}$ disubstituted flavone. A total fifteen carbon signals were observed in the ${ }^{13} \mathrm{C}-\mathrm{NMR}$ spectrum. These were assigned by DEPT experiments to fourteen $\mathrm{sp}^{2}$ carbons and a carbonyl signal at $\delta_{\mathrm{C}}$ 176.6. The degree of unsaturation was accounted for eight out of the total eleven double bond equivalents. The remaining three degree of unsaturation were consistent to flavonol structure (Kim et al., 2016; Aisyah et al., 2017). A comparison of the NMR data of $\mathbf{1}$ with those of kaempferol (Castenada et al., 2016; Aisyah et al., 2017), revealed that the structures of the two compounds are very similar, therefore, compound $\mathbf{1}$ was identified as kaempferol, which shown in this plant for the first time.

Compound 2 was obtained as a yellow amorphous powder. The LC-MS of $\mathbf{1}$ gave a ion peak at $\mathrm{m} / \mathrm{z} 300$, compatible with the molecular formula $\mathrm{C}_{15} \mathrm{H}_{10} \mathrm{O}_{7}$. Its $\mathrm{UV}$ absorptions in $\mathrm{MeOH}$ were consistent with the presence of a 3, 5, 7, 3', 4'pentahydroxyflavone structure (Kim et al., 2016; Aisyah et al., 2017). The ${ }^{1} \mathrm{H}-$ and ${ }^{13} \mathrm{C}-$ NMR spectra of $\mathbf{1}$ exhibited resonances due to aromatic systems. The ${ }^{13} \mathrm{C}-\mathrm{NMR}$ signals of $\mathbf{1}$ were assigned with the help of a DEPT experiment. In the ${ }^{1} \mathrm{H}-\mathrm{NMR}$ spectrum of $\mathbf{1}$, the aromatic region exhibited an $\mathrm{ABX}$ system at $\delta_{\mathrm{H}} 7.73\left(1 \mathrm{H}, \mathrm{d}, J=2.0 \mathrm{~Hz}, \mathrm{H}-2^{\prime}\right), 7.62(1 \mathrm{H}, \mathrm{dd}$, $\left.J=2.0,7.5 \mathrm{~Hz}, \mathrm{H}-6^{\prime}\right)$, and $6.87(1 \mathrm{H}, \mathrm{d}, J=8.0$ $\left.\mathrm{Hz}, \mathrm{H}-5^{\prime}\right)$ due to a $3^{\prime}, 4^{\prime}$ disubstitution of ring $\mathrm{B}$ and a typical meta-coupled pattern for $\mathrm{H}-6$ and $\mathrm{H}-8$ protons $\left(\delta_{\mathrm{C}} 6.17\right.$ and $6.37, \mathrm{~d}, J=2.5$ $\mathrm{Hz})$. The ${ }^{13} \mathrm{C}-\mathrm{NMR}$ spectrum of $\mathbf{1}$ showed the presence of 15 aromatic carbon signals. Based on the NMR data and comparison of the data given in the literature previously, the structure of compound $\mathbf{2}$ was identified as quercetin (Huang et al., 2013), which shown in this plant for the first time.<smiles>O=c1c(O)c(-c2ccc(O)cc2)oc2cc(O)cc(O)c12</smiles> 
The effect of kaempferol and quercetine on the viability of SP-C1 cells was evaluated according to the methodology described in previous papers (Prayitno et al., 2013). The treatment of cancer SP-C1 cell lines with kaempferol and quercetine resulted in a dosedependent inhibition of cell growth, as demonstrated by the MTT assay. Twenty-four hours of treatment with kaempferol and quercetine inhibited the proliferation of SPC1cells with an $\mathrm{IC}_{50}$ value of 2.50 and 2.31 $\mu \mathrm{M}$, indicating that both compounds are potential for further application in cancer treatment.

\section{CONCLUSIONS}

Two known flavonoid componds kaempferol (1) and quercetin (2) have been isolated from the leaves of Altingia excelsa Nornha. Quercetin showed stronger antiproliferative activity against SP-C1 cancer tongue cells, suggested the presence of additional hydroxyl group in flavonoid structure can increase antiproliferative activity.

\section{ACKNOWLEDGEMENTS}

This investigation was financially supported by Lembaga Pengelola Dana Pendidikan (LPDP) and Directorate General of Higher Education, Ministry of Science, Technology and Higher Education, Indonesia (2015). We thank Mr. Ahmad Darmawan and Mrs. Sofa Fajriah in the Research Center for Chemistry, Indonesian Science Institute, for NMR and LC-ESI-MS measurements.

\section{REFERENCE}

Aisyah LS, Yun YF, Herlina T, Julaeha E, Zainuddin A, Nurfarida I, Hidayat AT, Supratman U, Shiono Y. 2017. Flavonoid compounds from the leaves of Kalanchoe prolifera and their cytotoxic activity against P-388 Murine leukimia cells. Natural Products Sciences. 23(2): 139145.

Castenada HGT, Dulcey AJ, Martinez JHI. 2016. Flavonoid Glycosides from Siparuna gigantotepala Leaves and Their Antioxidant Activity. Chem. Pharm. Bull. 64: 502-506.
Chen YJ, Chang JT, Liao CT, Wang HM, Yen TC, Chiu CC. 2008. Head and neck cancer in the betel quid chewing area: recent advances in molecular carcinogenesis. Cancer Sci. 99(8): 1507-1514.

Chen SF, Nien S, Wu CH, Liu CL, Chang CY, Lin YS. 2013. Reappraisal of the anticancer efficacy of quercetin in oral cancer cells. Journal of chinese medical association. 76: $146-152$

Huang W, Wan C, Zhou S. 2013. Quercetin-a flavnoid compound from sarcopyramis bodinieri var delicate with potential apoptotic activity in HepG2 liver cancer cells. Tripical Journal of Pharmaceutical Research. 12(4): 529-533.

Kanjilal PB, Kotoky R, Singh RS. 2003. Chemical composition of the leaf oil of Altingia excelsa Nornha. Flavour Fragr. J. 18: 449-450.

Kim JW, Kim TB, Yang H, Sung SH. 2016. Phenolic compounds isolated from Opuntia ficus-indica Fruits. Natural Products Sciences. 22(2): 117-121.

Prayitno A, Asnar I, Putra ST. 2013. The relationship between mouth squamous cell carcinoma (MSCC) with HPV infection and the presence of p53 \& c-myc Mutation. Journal of Cancer Therapy. 4: 939-943.

Pramono AA, Djam'an DF. 2002. Tumbuhan rasamala. Balai Penelitian dan Pengembangan Teknologi Perbenihan. Bogor.

Scully C, Bagan J. 2009. Oral squamous cell carcinoma overview. Oral Oncol. 45: 301308.

Shah JP, Gil Z. 2009. Current concepts in management of oral cancer surgery. Oral Oncol. 45: 394-401.

Tan W, Lu J, Huang M, Li Y, Chen M, Wu G, Gong J, Zhong Z, Xu Z, Dang Y, Guo J, Chen X, Wang Y. 2011. Anti-cancer natural products isolated from chinese medicinal herbs. Chinese Medicine. 6: 2737. 